\title{
The 21st International Geological Congress, Norden 1960
}

\begin{abstract}
The 21st International Geological Congress (IGC) was held in Copenhagen, Denmark in 1960, but was organised jointly by the five Nordic countries. It attracted 2,386 geoscientists and 948 accompanying members and was up till then the largest scientific congress held in Copenhagen. It also had more members than any previous IGC. The paper presents an overview of the practical arrangements, the lecture sessions, and the excursions, and evaluates the outcome of the Congress. The meeting took place at the threshold of the formulation of the plate-tectonic concept, which, however, was hardly discernible in the Congress Proceedings. The 430 oral presentations and 407 printed papers nevertheless supplied new information in many fields of geology, examples of which are mentioned in the present paper.
\end{abstract}

\section{Introduction}

The 33rd International Geological Congress (IGC) to be held in Oslo in 2008 will be the third one to be located in a Nordic country. The 11th IGC took place in Stockholm in 1910 and the 21st in Copenhagen in 1960. The 879 registered members at the Stockholm Congress, 625 of whom were present, came from thirty-six countries. The number of participants was of the same manageable size in the subsequent congresses, but it increased markedly after the Second World War: 1,276 geoscientists from 84 countries were in London in 1948 and 2,120 from 105 countries attended the meeting in Mexico in 1956.

When, during the 1956 IGC, the delegates from Denmark, Finland, Iceland, Norway and Sweden were requested to examine the possibility that the next Congress could be hosted by one of their countries, they realized that the 21 st Session of the IGC was likely to reach a size that would exceed the capacity of a single small country. They therefore accepted to organize the Congress as a joint venture-the one and only such meeting of the IGC thus far. Copenhagen was chosen as the site for the sessions of the Congress. The excursions were the responsibility of each of the five countries.

\section{The traditional Nordic cooperation}

The decision to arrange the 21 st IGC as a joint Nordic project was a natural consequence of the cooperation between the Nordic countries, which had evolved during more than hundred years. The scientific cooperation can be traced back to 1839 , the year when the first Nordic scientific assembly was convened in Gothenburg, Sweden. This was a remarkable event. The Nordic countries had been through turbulent times during the Napoleonic wars and Denmark and Sweden in particular had been engaged in a number of mutual wars in the preceding centuries. There was, however, at the time of that assembly a general feeling that the Nordic countries had much in common and formed a special group of European nations. The meeting was one of the many expressions of this common Nordic ethos. It demon- strated that the researchers had much to gain by combining their efforts. Therefore, a second assembly, which attracted 300 naturalists, was convened in Copenhagen in the following year, and such meetings were arranged at intervals of two to six years until the 15th assembly in 1898. There was then a pause of eighteen years. But in 1916, the 16th Nordic naturalists' assembly encouraged the scientific societies, which had by then been established in all the Nordic countries, to foster Nordic cooperation in their various programmes. The Geological Society of Denmark responded by convening the first Nordic geological summer meeting. Forty four geologists from Denmark, Norway and Sweden participated in an excursion to Northern Jutland in the summer of 1918. Eventually, the cooperation established between the various scientific societies made the naturalist meetings redundant and they ceased with the 19th meeting in 1936.

The Nordic geological summer meetings consisting of lecture sessions and excursions were arranged at four-year intervals until 1958 when the last one was convened in connection with the centenary celebrations of the Geological Survey of Sweden. Nordic geological winter meetings were initiated in 1954 and have subsequently been the main contact forum for Nordic geoscientists. They take place every second year in turn in the five countries. The 27th meeting was held in 2006.

Nordic geological cooperation was marked by the founding of the international scientific journals Lithos, Lethaia, and Boreas in the 1960s. In addition, the Nordic countries jointly established a volcanologic research institute in Reykjavik and summer schools in Iceland for Nordic students of geology and geography. The five countries also collaborate to make expensive instruments available to members of the Nordic scientific community, an example being the ion probe in Stockholm.

The Nordic delegates to meetings of international organisations such as the IGC Council generally meet before the sessions to discuss the agenda and often coordinate their views. This 'Nordic solidarity' has been noted by delegates from other countries. I have myself had the experience that the chairman of a business meeting of a European scientific organisation asked: “... and what is the view of the Nordic mafia?". In any case, solidarity makes for strength and made it possible to convene the 21 st IGC and the forthcoming 33rd meeting.

\section{The organization of the 21st Congress}

The 21st IGC had 3,379 members from 101 countries. 2,386 of these actually attended the Congress and there were 948 accompanying members.

The geographical provenience of the attending members, expressed as percentages, was:

\begin{tabular}{lcc} 
& Countries & Participants \\
Nordic countries & $5 \%$ & $12 \%$ \\
Other European countries & $28-$ & $38-$ \\
North America & $3-$ & $36-$ \\
Latin America & $16-$ & $3-$ \\
Africa & $27-$ & $6-$ \\
Asia & $16-$ & $3-$ \\
Australia and Oceania & $5-$ & $1-$ \\
\hline
\end{tabular}




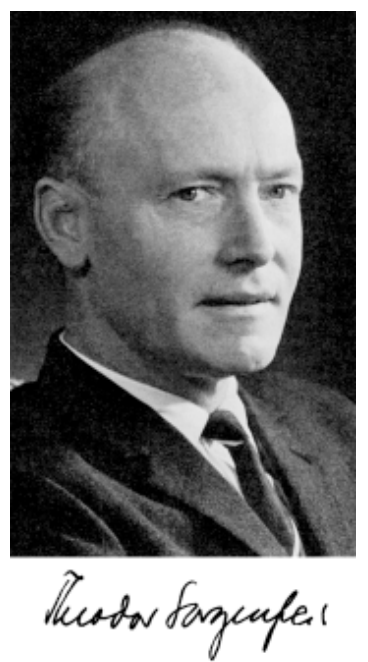

Figure 1 Theodor Sorgenfrei (1915-1972), professor at the Technical University of Denmark, Secretary General of the 21st International Geological Congress.

The total cost of the Congress, including the printing of the twenty eight volumes of the Proceedings amounted to 1.1 million DKK. Participant fees covered 55\%, contributions from other Nordic countries $25 \%$, and sponsors $20 \%$. To this should be added the value of the voluntary assistance from the Danish geological community.

The number of participants precluded the arrangement of social events for all of them together, with the exception of an evening in the Tivoli Pleasure Gardens, which included a concert in its concert hall. However, delegates were received in the Parliament and by the Mayor of Copenhagen in the Town Hall, where they had the opportunity to taste the celebrated "Townhall Pancakes". The Carlsberg and Tuborg breweries cheerfully opened their doors to the participants and their relatives and offered ample opportunities for sam-

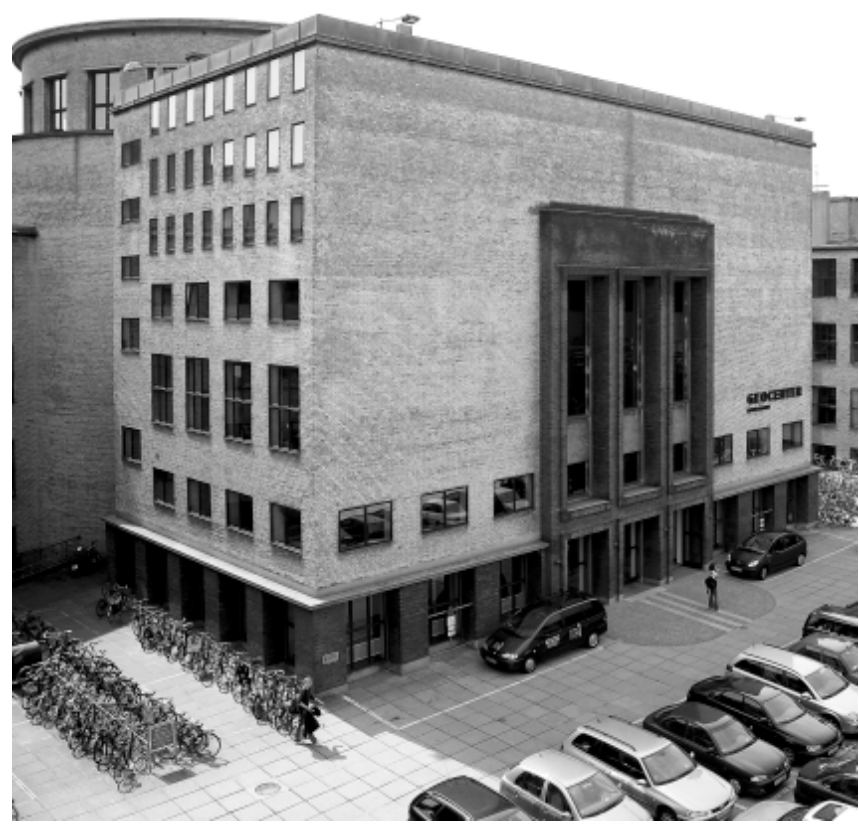

Figure 2 The building Øster Voldgade 1, the site of the 21st IGC and now accommodating Geocenter Copenhagen (GEUS photo).

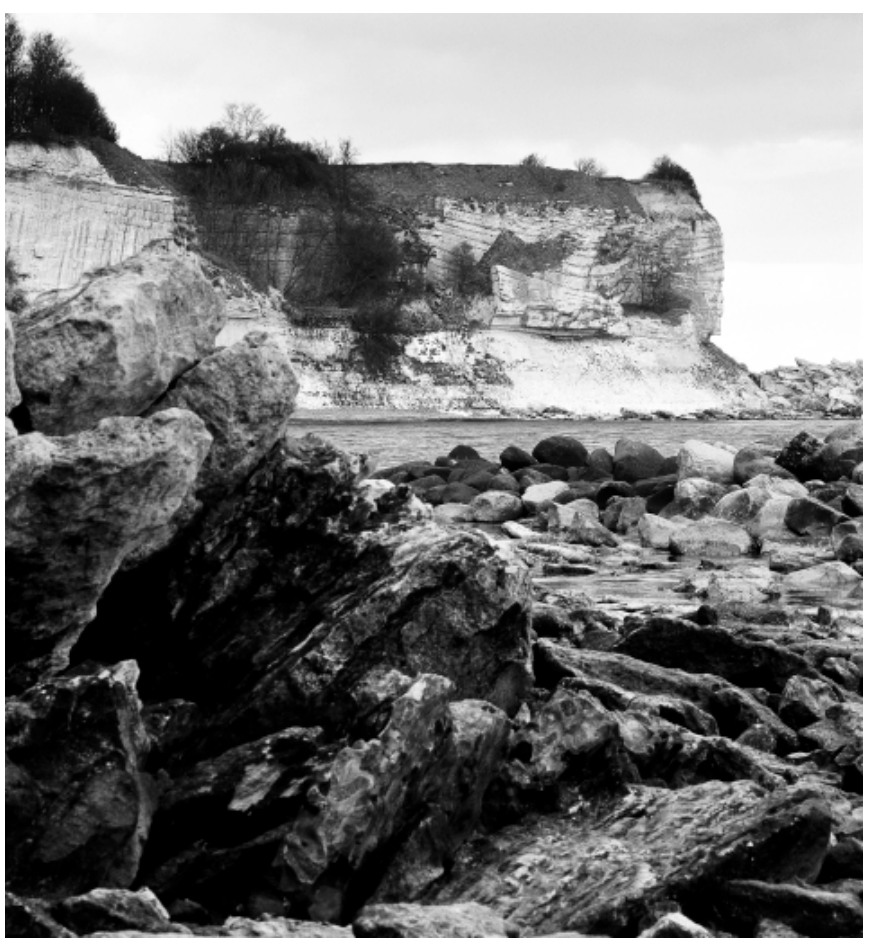

Figure 3 Stevns Klint south of Copenhagen, the type locality of the Danian. The lower part of the cliff is made up of Senonian chalk, the upper part of Danian Bryozoan Limestone. The Cretaceous-Tertiary boundary is the sharp boundary between the overhanging Danian and the lower chalk. Note the lenticular bodies of flint in the Senonian and the flint horizons in the Bryozoan Limestone (GEUS photo).

pling their products. Afternoon tea and mannequin parades were arranged for accompanying members at the Hotel d'Angleterre, the top hotel in town. A number of tours by bus and by boat were arranged in Copenhagen and its surrounds. One tour went to the city of Odense to visit the birth place of Hans Christian Andersen, another to Stevns Klint, the type locality of the Danian and the famous exposure of the Cretaceous-Tertiary boundary.

The excursions, which included visits to most corners of the five Nordic countries, attracted 1,824 participants. There were thirtythree excursions before, and thirty-five after, the lecture and council sessions in Copenhagen. One excursion came as far north as Svalbard, but the scheduled excursion to West Greenland unfortunately had to be cancelled because of a lack of ship capacity, caused by the shipwreck of the flag-ship of the Greenland Shipping Company in January 1959. Together, the 1,642 pages of the forty-three guide books give an overview of the geology of the Nordic countries. The travelled distances of the excursions added up to $104,017 \mathrm{~km}$. There were ten accidents: a bus collision with nobody hurt; a thorn in a leg; four wounded hands; two splinters in eyes; and two in legs. In his final report, the Secretary General of the Congress ascribed the eight last-named accidents to poor hammer discipline! I endorse this statement, having found that excursions always have at least one participant who uses the hammer without paying proper attention to the surroundings.

Eight commissions of the IGC and eight international scientific organisations convened in Copenhagen during the days of the Congress.

The lecture program comprised twenty-one sections (see the list of the Proceedings at the end of the paper). The organisation committee sensibly decided that the printed papers should be available at the opening of the Congress " ... in order to secure better discussions during the sessional meetings ..." This decision presented a serious challenge to the authors and not least to the Congress Secretariat and 

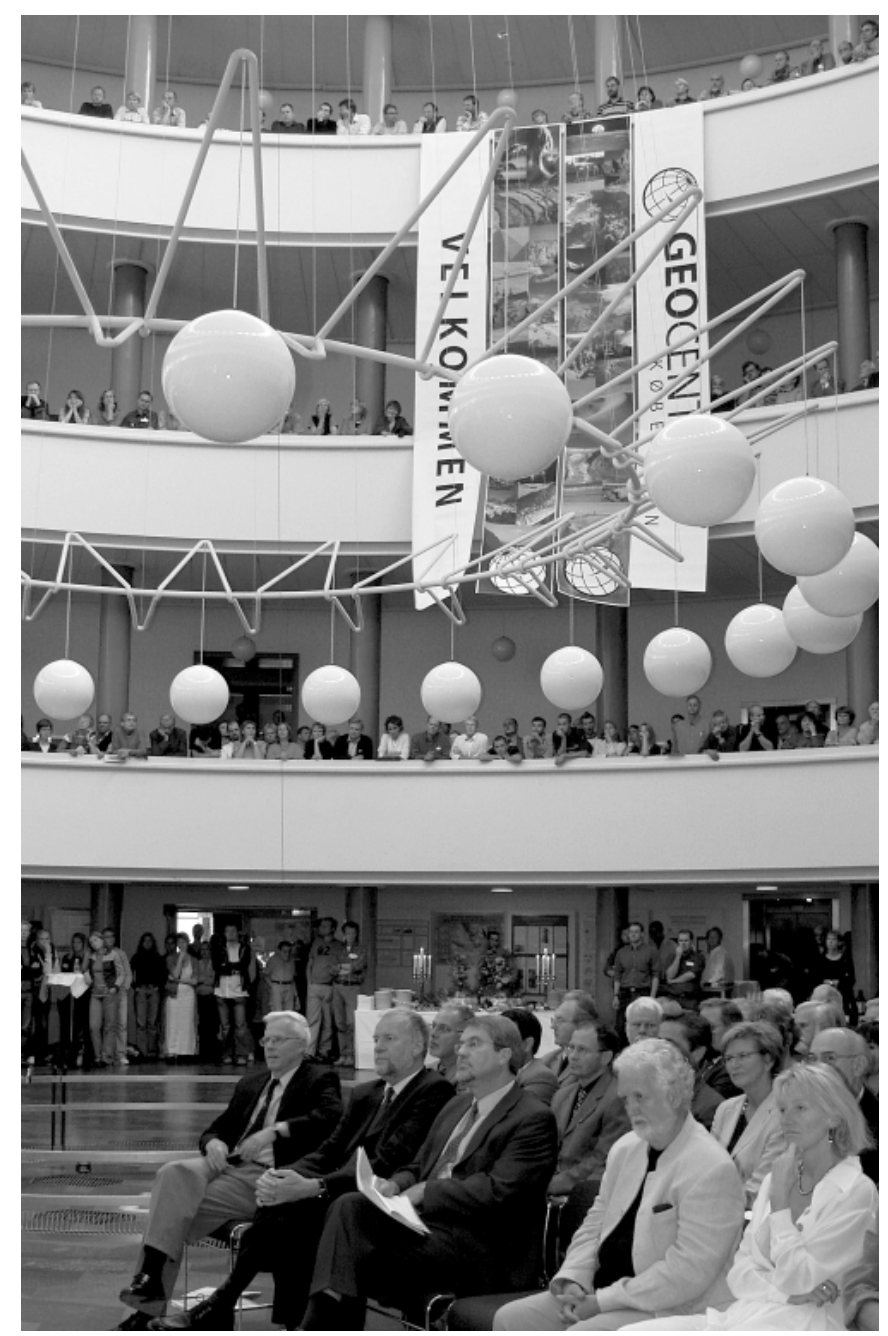

Figure 5 The central hall of Geocenter Copenhagen on 16 September 2002, the day of the official opening of the Geocenter. First row from left to right: Martin Ghisler, managing director of the Geological Survey of Denmark and Greenland (GEUS), Per Buch Andreasen, chairman of the board of GEUS, Leo Larsen, the then head of the department of the Ministry of the Environment, Henrik Jeppesen, the then Dean of the Faculty of Natural Sciences and Linda Jensen, the then Rector of the University of Copenhagen. This hall was the centre of the activities of the 21st IGC.

the session conveners, who had very little time for writing and handling the manuscripts. (Being myself a co-convener of one of the sessions and member of the editorial committee, I can personally endorse this statement). 977 abstracts were received but only 557 manuscripts were eventually handed in, of which 430 were accepted for oral presentation and 407 were printed in twenty-one volumes, one for each session. In his final report, the Secretary-General of the Congress expressed satisfaction and pride that the twenty-one volumes were on the desk at the opening of the Congress. After having participated in subsequent IGCs, my experience is that the programmes are so tight that little time is left for reading the papers. In recognition of this, there has generally been a desk where the participants, immediately after having received the publications, can wrap them up and hand the package in for sending home, at own cost, for their later perusal. I nevertheless think that the pre-Congress availability of the publications was justified. It saved a large sum of money for the organisers, and the participants had the opportunity to pick up papers that were of particular interest to them. Electronic publication will solve this problem in the future. The Proceedings volumes 22 to 28 were published after the Congress.

\section{The Proceedings of the twenty-one lecture sections}

The Proceedings volumes reveal that most lectures and interrogations dealt with descriptive themes which supplied substantial new information about a broad range of geological topics. Only a minor proportion of the presentations dealt with more general issues, and still fewer described entirely new developments.

I have refreshed my memory by reading abstracts, the discussion volume, and a number of the papers within my fields of expertise and have on this basis prepared the following brief survey of papers, which I consider to be state-of-the-art presentations of geological materials, processes, phenomena and regional features, and presentations of new developments. The numbers in brackets refer to the numbers of the volume of the Congress publications.

- Problems of estimating abundances of elements in the Earth's crust: M. Fleischer and E.C.T. Chao (1).

- Aspects of Pre-Quaternary age determinations (3): papers by R.E. Folinsbee, H. Baadsgaard \& J. Lipson, J.L. Kulp, L.N Ovchinnikov and M.A. Harris, and H. Faul.

- Pre-Cambrian and Cambrian stratigraphy and fossils: papers by N.S. Schatsky, V.V. Menner and B.P. Thomson (8), A.M. Quennell and E.G. Haldemann (9), A.A. Polkanov and E.K. Gerling (9), and A.P. Vinogradov et al. (9).

- Hitherto unavailable information about the oil and gas deposits in Siberia (11): C.A. Belov et al., K.R.Chepikov et al., V.D. Nalivkin and V.P. Kazarinov et al.

- One of the first convincing demonstrations of liquid immiscibility during crystallization of basaltic magmas: H.I. Drever (13).

- Layered intrusions: A. Poldervaart and W.H. Taubeneck (13).

- Fluid inclusions as samples of ore-forming fluids: E. Roedder (16).

- Enclaves in granite, introduction to a French speciality: J. Didier and M. Roques (14).

- T.F.W. Barth and the present writer convened a symposium on migmatite nomenclature (26).

- P.J. Wyllie and O.F. Tuttle presented experimental verification of the magmatic origin of carbonatites - a bench-mark paper and one of the highlights of the Congress (13), and also presented experimental verification of melting processes in the Earth's crust (18).

- E. Scádecsky-Kardoss proposed a genetic system of igneous rocks (13) and together with G. Pantö and V. Széky-Fux (13) called for a uniform nomenclature of igneous rocks. This did not gain support. A. Streckeisen, who was present, took up the idea. He had a proposal for an IGC activity ready for the 23 rd IGC in Prague in 1968, but it did not eventuate because of the military intervention in Czechoslovakia which interrupted the Congress. The project was eventually initiated during the 24th IGC in Montreal in 1972 and the results of the work were presented at the 28th IGC in Washington DC in 1989. (I add this information in my capacity as a member of the Streckeisen team during the whole period).

- In 1960, it was the common belief that nuclear power should cover a major part of the future energy supply. This prompted a worldwide search for uranium deposits and one lecture session was devoted to the genesis of uranium and thorium ores. R.D. Nininger and L.R. Page lectured on respectively the genesis and the source of uranium deposits (15).

- L.U. de Sitter and H.J. Zwart described the relationship between deformation and metamorphism in supra- and infrastructures of orogens (18). 
- Paleogeography and stratigraphic facies (12): L.L: Schloss about North America; V.E. Khain and A.B. Ronov about the Mesozoic world; A.P. Vinogradov et al. about the Russian platform.

- C.J.G. Guillemin and M. Capitant introduced the then new instrument, the electron microprobe invented by R. Castaing (21).

- Lectures by K. v. Bülow, J. Green and A. Poldervaart and P.J. Schlichta marked the new research field directed towards the moon and the planets (21).

In addition, the International Paleontological Union, the International Asssociation of Sedimentology, the International Committee for the Study of Clays, and the Geochemical Society arranged lecture sessions and symposia. One symposium directed by A. von Valkenburg and M. Fleischer discussed the international geochemical standards. The International Mineralogical Association arranged symposia on mineral synthesis and on feldspars. In volume 25 of the Proceedings, the Stratigraphical Subcommission of IGC presented Principles of Stratigraphical Classification and Terminology, a chart of Units of Stratigraphical Classification and a Glossary of Terms.

I have made a special effort to examine whether topics, such as plate tectonics, mass extinction, climate change and environmental geology, which are to the fore today, were treated in any way in 1960.

The deadline for abstracts was 1 April, 1959, and for manuscripts 1 September, 1959. This was well before the theoretical break-through leading to the plate-tectonic model. Only three of the architects of the new model attended the Congress: J. Tuzo Wilson, S.W. Carey and B.C. Heezen. The last-named gave a talk on primary structures in deep sea sediments (which was not published). He participated in the discussion of the paper on paleomagnetic dating of glaciations in Iceland by M.G. Rutten and H. Wensink (18), which was one of the fundamental papers on a method which a few years later produced some of the results that led to the concept of plate tectonics. The Section on submarine geology (10) had only seven contributions which mainly dealt with sedimentological topics. The papers in the session on the structure of the Earth's crust and deformation of rocks (18) dealt mainly with regional features and with rock geometry and rock mechanics. More general papers by $\mathrm{E}$. Kraus, R.W. van Bemmelen, and V.V. Beloussov marked the pre-plate tectonic state of knowledge and theory about mountain building and orogens emphasising the importance of geosynclines and of vertical uplift rather than crustal shortening. Contraction of the Earth (V.E. Khain) or an expanding Earth (A.J. Shneiderov) were also considered. B.V. Stoč es (whose paper was not published) explained the movement of continental blocks and the origin of Alpine type folds by some kind of horizontal force which he related to the rotation of the Earth. A number of papers dealing with peridotites and other ultramafic rocks (13) clearly show that the nature of Alpine-type peridotites and ophiolite complexes, as accepted today, was not yet understood. Papers by J.A. Noble and H.P. Taylor, C.W. Chesterman and T.P. Thayer invoked the intrusion of peridotite magmas or of crystal 'mushes' when interpreting the emplacement of these rocks. Thus, my survey of the publications of the 21 st IGC has found no intimations of the approaching plate-tectonic revolution.

The Cretaceous-Tertiary boundary was ostensibly the subject of Section 5, but it mainly discussed the place of the Danian in the stratigraphical column. The extinction of the dinosaurs and the different behaviour of pelagic and benthonic foraminifera were mentioned cursorily. (The impact theory of mass extinction was advanced nineteen years later at another conference in Copenhagen. )
Section 4 was devoted to the chronology and climatology of the Quaternary. It mainly dealt with stratigraphical problems; global warming was not yet on the agenda. V.I. Gromov et al. (4) proposed that the term Quaternary should be replaced by Anthropogene, which according to the minutes of the session this suggestion found no support.

Section 20 on applied geology had twelve contributions dealing with ground water, engineering geology and aspects of ore geology. Environmental geology was not yet conceived. (Peter T. Flawn's epoch-making book Environmental Geology only appeared in 1970.)

\section{What came out of the 21st IGC ?}

One immediate answer is that for me, then in an early stage of my career, the Congress opened the window to the international geological world. I had already some international experience and enjoyed meeting acquaintances from study visits and scientific conferences in other countries, to see and listen to a number of prominent authors of textbooks and trend-setting papers. The contacts established gave my career and life an international dimension. I believe that the same happened to most other participants. In itself, this outcome justifies the organization of large international meetings.

In 1960, the Iron Curtain made it difficult to contact Russian colleagues. But quite a large group of Soviet geoscientists participated in the Copenhagen Congress. Some of the top Soviet geoscientists gave lectures: D.S. Korzhinsky on acidity-alkalinity in magmatic processes (21); A.A. Polkanov on the Pre-Cambrian geochronology of the Baltic shield (9); N.P. Semenenko on metamorphism of mobile belts (14); V.I. Smirnov on the hypogene zonality of hydrothermal ore bodies (16); V.S. Sobolev on the role of high pressure in metamorphism (14); and A.P. Vinogradov on the geochemical cycles of lead isotopes (not published). These influential geoscientists kindly helped a number of us to establish contact with Russian counterparts, in my case to colleagues who were world leaders in the study of the types of alkaline rocks that I investigated in Greenland. This developed into a still-lasting cooperation.

As said, the major part of the presentations at the Congress were descriptive, a minor part of a more general nature, and very few were really innovative. One may say that the geosciences was holding its breath at the threshold to the break-through of the platetectonic model which was formed step by step during the following decade and to the new role of the geosciences as a foundation for sustainable development - the theme of the 33rd IGC in Oslo.

In recognition of this, it may be concluded that apart from the many personal contacts which were established, the main outcome of the 21 st IGC was that it gave birth to the International Union of the Geological Sciences-IUGS.

In Denmark, the Congress attracted some public attention to geology and geologists. It is, however, impossible to judge whether in itself boosted the development of geology in the country since an energetic expansion of universities and science in Denmark was then already going on. The mastermind behind this expansion in education and research was the visionary Prime Minister Viggo Kampmann, who addressed the participants at the opening ceremony of the Congress.

The 21st IGC was held in the main buildings of The Technical University of Denmark. These buildings now house Geocenter Copenhagen where the University's Geology and Geography Institutes and the Geological Survey of Denmark and Greenland live side by side under the same roof. The Geography and Geology Institutes were amalgamated into one institution on 1 January 2007. 


\section{List of the publications of the 21st IGC}

\author{
International Geological Congress \\ Reports of the Twenty-First Session Norden \\ Denmark-Finland-Iceland-Norway-Sweden \\ 1960, Copenhagen
}

Volume of Abstracts, 1960, $252 \mathrm{pp}$.

Volume 1. Geochemical cycles, 1960, 148 pp.

Volume 2. Geological results of applied geochemistry and geophysics, 1960, $215 \mathrm{pp}$.

Volume 3. Pre-Quaternary absolute age determination, 1960, 49 pp.

Volume 4. Chronology and climatology of the Quaternary, 1960, 169 pp.

Volume 5. The Cretaceous-Tertiary boundary, 1960, $215 \mathrm{pp}$.

Volume 6. Pre-Quaternary micropaleontology, 1960, 143 pp.

Volume 7. Ordovician and Silurian stratigraphy and correlation, 1960, 157 pp.

Volume 8. Late Pre-Cambrian and Cambrian stratigraphy, 1960, 118 pp.

Volume 9. Pre-Cambrian stratigraphy and correlations, 1960, 206 pp.

Volume 10. Submarine geology, 1960, $85 \mathrm{pp}$.

Volume 11. Regional and structural problems in oil geology, 1960, 123 pp.

Volume 12. Regional paleogeography, 1960, $220 \mathrm{pp}$.

Volume 13. Petrographic provinces, igneous and metamorphic rocks, 1960, $461 \mathrm{pp}$.

Volume 14. The granite-gneiss problem, 1960, $250 \mathrm{pp}$.

Volume 15. Genetic problems of uranium and thorium deposits, 1960, 164 pp.

Volume 16. Genetic problems of ores, 1960, $268 \mathrm{pp}$.

Volume 17. Minerals and genesis of pegmatites, 1960, $136 \mathrm{pp}$.

Volume 18. Structure of the Earth's crust and deformation of rocks, 1960, $470 \mathrm{pp}$.

Volume 19. Caledonian orogeny, 1960, $163 \mathrm{pp}$.

Volume 20. Applied geology, 1960, 93 pp.

Volume 21. Other subjects, 1960, 325 pp.

Volume 22. International Paleontological Union, 1960, 123 pp.

Volume 23. International Association of Sedimentology, 1961, 142 $\mathrm{pp}$.

Volume 24. International Committee for the Study of Clays, 1961, 111 pp.

Volume 25. The Stratigraphic Classification and Terminology, 1961, 38 pp.

Volume 26. Supplementary volume, 1961, $133 \mathrm{pp}$.

Volume 27. Contributions to discussions, 1963, $262 \mathrm{pp}$.

Volume 28. General proceedings, 1964, 375 pp.

\section{List of excursions}

The names of the leaders are in brackets. Many excursions had more than two leaders, in that case only the senior leader is mentioned. The low number of excursions in Iceland and Denmark is a consequence of the small size of these countries; additionally that in Denmark the whole geological community was engaged in organising and running the Congress. Most excursions were held before as well as after the lecture sessions.

\section{Denmark}

Geology of South-Eastern Sjælland, Møn and Northeastern Jylland (A. Rosenkrantz et al.).

Glacial geology of Southern Denmark (S. Hansen et al.).

Geology of Bornholm (H. Gry et al.).

The Paleozoic of Bornholm (C. Poulsen).

Sedimentary and economic geology of Denmark (K. Hansen et al.).

\section{Finland}

Precambrian geology, Southern Finland (A. Simonen, A. Matisto). Precambian geology, Finland (M. Härme, M. Lehijärvi).

Geology of the Archipelago of Southwestern Finland (A. Metzger, B. Öhman).

Mining geology of Finland (P. Haapala, O. Kouvo).

Nonmetallic mineral deposits, Finland (E. Aurola et al.).

Non-metallic mineral deposits in Finland (K.J. Neuvonen, A. Vesasalo).

Quaternary geology of Eastern and Northern Finland (E. Hyppä, M. Salmi).

Southeastern Finland, a general excursion (T. Mikkola, M. Okko).

\section{Iceland}

The geology and geophysics of Iceland (S. Thorarinsson et al.).

\section{Norway}

Aspects of the geology of Northern Norway (O. Holtedahl et al.)

Stratigraphy and volcanism of the Trondheimsfjord Area.

(H. Carstens, F.C. Wolf).

The relationship between Cambro-Silurian schists and the gneiss complex in the Deep-Caledonides of Sogn and Fjordene, West Norway (N.-H. Kolderup, I. Bryhni).

Mountain, fjord, strandflat; geomorphology and general geology of parts of Western Norway (H. Holtedahl et al.)

The Nappe Area of the Caledonides in Western Norway (A. Kvale, M.A. Sellevoll).

Precambrian gneisses and granites of the Skagerrak coastal area, South Norway (T.F.W. Barth et al.).

The geology of the catazone: the problem of the anorthosites, the basic palingenesis and the catazonal tectonics in southern Rogaland (S. Norway) (P. Michot).

The stratigraphy of supracrustal rocks, granitization and tectonics in the Precambrian Telemark area, Southern Norway (O.A. Broch et al.).

Permian igneous rocks of the Oslo graben (Chr. Oftedahl).

Larvikite and nepheline syenite pegmatite minerals, per-alkaline rocks in the Larvik-Langesund areas, South Norway (I.W. Oftedahl, S. Svinndal).

Srtratigraphy, petrology and Caledonian nappe tectonics of central Southern Norway, Caledonized basal gneisses in a Northwestern area (Oppdal-Sunndal) (T. Strand et al. ).

Mines in South and Cental Norway (O. Adamsson et al.)

Paleozoic stratigraphy and paleontology of the Oslo Region, Eocambrian stratigraphy of the sparagmite region, Southern Norway (L. Störmer et al. ).

Mineral occurrences in Southern Norway (H. Neumann, T. Sverdrup).

Aspects of the geology of Svalbard (T. Winsnes, A. Heintz).

Marine clays and quick clay slides in South and Central Norway (I. Rosenqvist).

Aspects of the geology of the central part of the Oslo Region (S. Skjeseth, F. Hagemann). 


\section{Sweden}

Aspects of Quaternary geology in Central Sweden (J. Lundqvist).

Recession of the Land ice in Southwestern Sweden (H. Tullström et al.).

The Mesozoic of Scania, Southern Sweden (F. Brotzen).

The lower Paleozoic of Scania, the Silurian of Gotland (G. Regnell, J.E. Hede).

The Cambrian, Ordovician, and Silurian in Västergötland, Närke, Dalarne. and Jämtland, Central Sweden (P. Thorslund et al.).

Studies in the thrust region of the southern part of the Swedish mountain chain (B. Asklund).

The Caledonian mountain chain in the Torneträsk-Ofoten area, Northern Scandinavia. The Kiruna iron ore field, Swedish Lapland (O. Kulling).

Iron and sulphide ores of Central Sweden (N. Magnusson).

Sulphide and iron ores of Västerbotten and Lappland, Northern Sweden (E. Grip et al.).

Development of gneisses and granites in Southern Sweden (S. Gavelin, P.H. Lundegårdh).

Archean geology of Västerbotten and Norrbotten, Northern Sweden (G. Kautsky et al.).

Alkaline rocks and mineral deposits of Southern, Central and Northern Sweden (H. von Eckermann).
Henning Sørensen, born in 1926. University of Copenhagen. Professor in Geology 1962-1992. Active professor emeritus since then. More than 300 publications on mineralogical and petrological subjects related to alkaline rocks, particularly the Ilimaussaq alkaline intrusion in South Greenland, and on mineral resources and other aspects of applied geology. 29 field expeditions to Greenland from 1946 to 2005. Prominent Danish scientist, former chairman of the Danish Natural Science Research Council and President of The Royal Danish Academy of Sciences and Letters. Active in promoting geology as an important factor to policy and decision makers. Introduced the discipline environmental geology in Denmark as early as in 1971. The mineral sørensenite - a rare sodiumberyllium-tin silicate only known from the Ilimaussaq intrusion-was described and named in honour of him by Russian and Danish mineralogists in 1966.

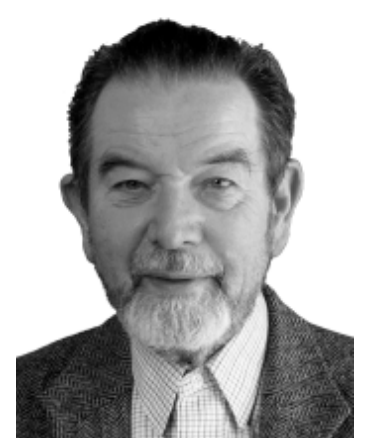

\section{Episodes is your window to the world. Subscribe today!}

\section{Episodes}

\section{Subscription Order}

Name (please print)

Address

City State/Prov.

Country Zip/Postal Code

Please begin my subscription:

$\begin{array}{llll}\text { March } & \text { June } & \text { Sept. } & \text { Dec. } \\ \text { Year } & \text { Y Year } & \text { Year } & \text { Year }\end{array}$

To start your subscription, fill in this form and mail to:

\section{Episodes}

P.O. Box 823

26 Baiwanzhuang Rd.,

Beijing 100037, China

Tel: +86-10-6832 0827; +86-10-68329084

Fax: +86-10-6832 8928

E-mail: episodes@public2.bta.net.cn
Payment may be made by:

- Checks (US \$ only) made payable to Episodes

- $\square \mathrm{JCB}$

$\square$ Visa

$\square$ American Express $\square$ Mastercard

Please quote account number, expiry date and signature.

Account\#

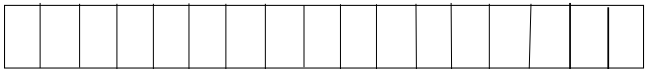

Expiry date

Signature

Annual subscription rates: US\$24 